\title{
Association between proximity to major roads and sputum cell counts
}

\author{
Julie Wallace $\mathrm{PhD}^{1}$, Liesel D'silva MD², John Brannan $\mathrm{PhD}^{2}$, Frederick E Hargreave MD FRCP FRCPC ${ }^{2}$, \\ Pavlos Kanaroglou PhD ${ }^{1}$, Parameswaran Nair MD PhD FRCP FRCPC ${ }^{2}$
}

\begin{abstract}
J Wallace, L D'silva, J Brannan, FE Hargreave, P Kanaroglou, P Nair. Association between proximity to major roads and sputum cell counts. Can Respir J 2011;18(1):13-18.
\end{abstract}

BACKGROUND: Air pollution caused by motor vehicle emissions has been associated with exacerbations of obstructive airway diseases; however, the nature of the resulting bronchitis has not been quantified.

OBJECTIVE: To examine whether proximity to major roads or highways is associated with an increase in sputum neutrophils or eosinophils, and to evaluate the effect of proximity to roads on spirometry and exacerbations in patients with asthma.

METHODS: A retrospective study of 485 sputum cell counts from patients attending a tertiary chest clinic in Hamilton, Ontario, identified eosinophilic or neutrophilic bronchitis. Patients' residences were geocoded to the street network of Hamilton using geographic information system software. Associations among bronchitis, lung function, and proximity to major roads and highways were examined using multinomial logistic and multivariate linear regression analyses adjusted for patient age, smoking status and corticosteroid medications.

RESULTS: Patients living within $1000 \mathrm{~m}$ of highways showed an increased risk of bronchitis (OR 3.8 [95\% CI 1.0 to 13.7$]$; $\mathrm{P}<0.05$ ), particularly neutrophilic bronchitis (OR 4.7 [95\% CI 1.2 to 18.7]; $\mathrm{P}<0.05$ ) as well as an increased risk of an asthma diagnosis (OR 1.9 [95\% CI 1.0 to 3.4]; $\mathrm{P}<0.05$ ). Patients living within $300 \mathrm{~m}$ of a major road were at increased risk for an asthma exacerbation (OR 1.9 [95\% CI 1.5 to 15.5]; $\mathrm{P}<0.01$ ) and lower lung function, particularly in women $(\mathrm{P}=0.036)$.

CONCLUSION: In patients with airway diseases, living close to a highway or major road was associated with neutrophilic bronchitis, an increased risk of asthma diagnosis, asthma exacerbations and lower lung function.

Key Words: Asthma; Bronchitis; Exacerbations; Geospatial analysis; Road traffic; Sputum cell counts

\author{
L'association entre la proximité des grandes routes \\ et la numération cellulaire des expectorations
}

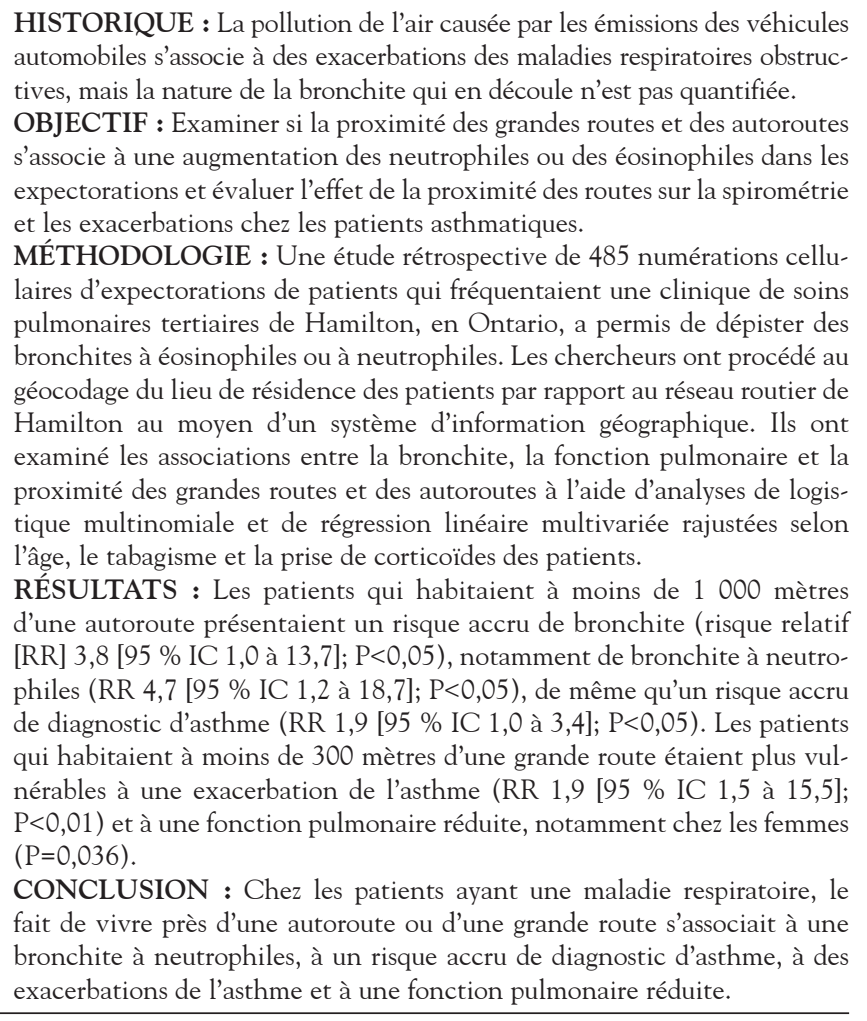
assessing the presence and severity of bronchitis (13) and are a routine test in our clinic. The Hamilton Census Metropolitan Area (Hamilton, Ontario) is located at the western tip of Lake Ontario, and has been well characterized for the effects of air pollution on morbidity and mortality (14). We assessed the relationship between the presence and severity of bronchitis in persons with airway diseases and proximity to major roads and highways using a spatial analysis approach with geographic information system (GIS) software and statistical methods. The primary objective was to examine whether proximity to major roads or highways is associated with an increase in sputum neutrophils or eosinophils, irrespective of the physiological abnormality (ie, asthma or chronic obstructive pulmonary disease [COPD]). The secondary objectives were to examine the effect of proximity to roads on spirometry and exacerbations in patients with asthma.

\section{METHODS}

Design

The present study was a retrospective survey of a computerized database of bronchitis measurements obtained from spontaneous or induced sputum cell counts of patients with airway diseases attending the outpatient clinic of the Firestone Institute for Respiratory Health

${ }^{1}$ Centre for Spatial Analysis, School of Geography and Earth Sciences; ${ }^{2}$ Firestone Institute for Respiratory Health, St Joseph's Healthcare and

Department of Medicine, McMaster University, Hamilton, Ontario

Correspondence: Dr Parameswaran Nair, Firestone Institute for Respiratory Health, St Joseph's Healthcare, 50 Charlton Avenue East, Hamilton,

Ontario L8N 4A6. Telephone 905-522-1155 ext 35044, fax 905-521-6183, e mail parames@mcmaster.ca 


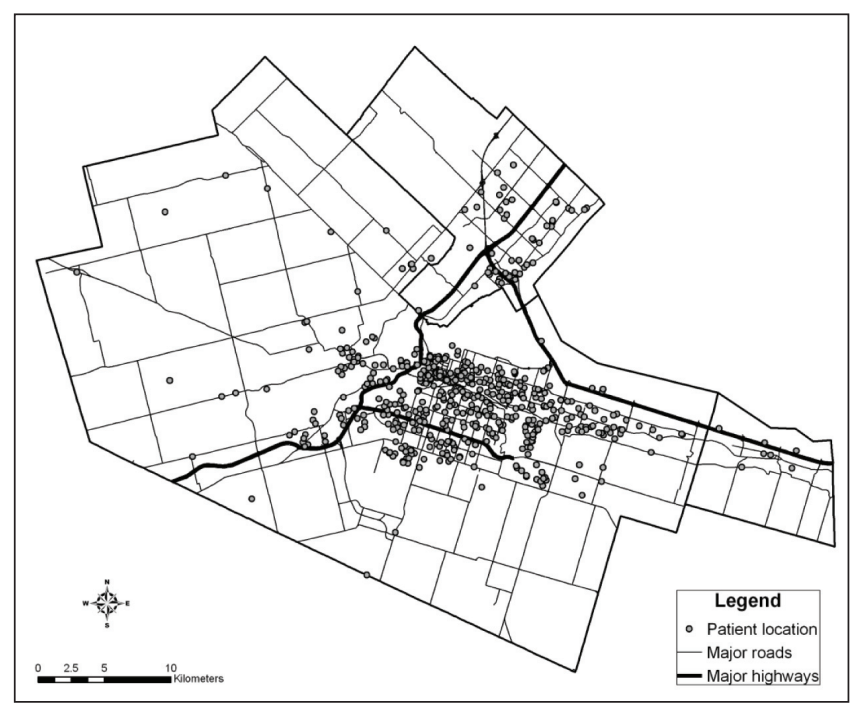

Figure 1) Geocoded addresses of patients in the Hamilton Census Metropolitan Area (Hamilton, Ontario)

(Hamilton, Ontario) between January 2004 and December 2006. Active bronchitis was defined as the presence of elevated levels of inflammatory cells in sputum. Bronchitis was further classified into two subtypes: eosinophilic (EB) (normal total cell count [TCC], eosinophils greater than $1.1 \%$ ) or neutrophilic (NB) (TCC greater than 10 million cells/g, neutrophils greater than 65\%) (15). Drawing from a database of 1076 patients, some with multiple visits, two subsets of data were extracted for analysis - the first with the initial visits of patients when they were stable $(n=485)$, the second with the first visits of patients when they experienced an exacerbation $(n=189)$.

A diagnosis of asthma was based on information provided by the referring physician, which included a compatible clinical history with evidence of reversible airflow limitation (increase in forced expiratory volume in $1 \mathrm{~s}\left[\mathrm{FEV}_{1}\right]$ of $15 \%$ or greater following a bronchodilator) or airway hyper-responsiveness (provocative concentration of methacholine causing a $20 \%$ fall in $\mathrm{FEV}_{1}$ ). COPD was defined as a postbronchodilator $\mathrm{FEV}_{1} /$ vital capacity (VC) of less than $70 \%$. An exacerbation was defined as an increase in cough, dyspnea, sputum volume or purulence, or a fall in $\mathrm{FEV}_{1}$ of at least $20 \%$ that, in the opinion of the referring physician, required an adjustment to therapy.

Sputum induction and examination of total and differential cell counts were performed as described by Pizzichini et al (16). Spirometry was performed according to standards of the American Thoracic Society. Moderate or many sputum macrophage inclusions were used as a marker of current or former cigarette smoking.

\section{Geographical analysis}

Geographical data were prepared using GIS software package ArcGIS 9.x (ESRI, USA). Patients' residences were geocoded to the street network of Hamilton (Figure 1). Roads were classified into two groups: provincial highways that carry high-volume, trans-province and transUSA traffic; and major roads of the local street network. For proximity analysis, patient addresses were assigned to spatial buffer zones of widths of $0 \mathrm{~m}$ to $500 \mathrm{~m}, 500 \mathrm{~m}$ to $1000 \mathrm{~m}$, and $1000 \mathrm{~m}$ to $1500 \mathrm{~m}$ that were created around provincial highways. Buffer zones of $0 \mathrm{~m}$ to $100 \mathrm{~m}$, $100 \mathrm{~m}$ to $200 \mathrm{~m}, 200 \mathrm{~m}$ to $300 \mathrm{~m}$, and $300 \mathrm{~m}$ to $400 \mathrm{~m}$ were created around major east-west roads. Proximity to the major industrial zone in Hamilton (Figure 2) was adjusted for by creating $1 \mathrm{~km}$ buffer zones around a centreline shown in Figure 2. The effect of the industrial zone itself was also investigated.

Buffer zone widths were selected based on the following three criteria: the need to spatially resolve the distances at which patients may be affected by pollution from vehicular traffic; the need to have an adequate number of patients in each buffer zone for statistical analyses;

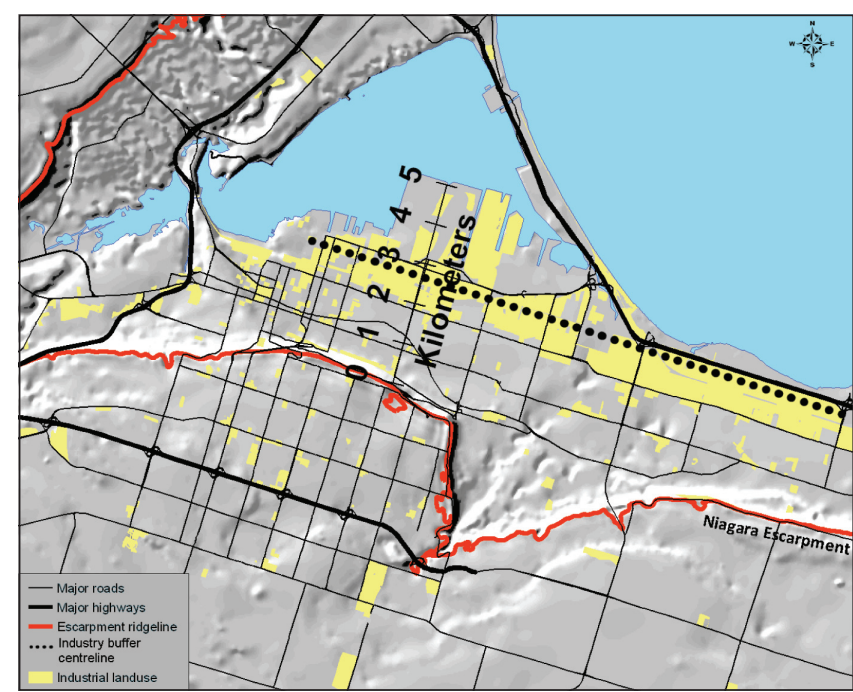

Figure 2) Hillshade of the central core of Hamilton, Ontario, showing the Niagara escarpment, the main industrial area and the centreline used to demarcate industry buffer zones

and to avoid overlap with buffer zones from neighbouring roads. Furthermore, previous studies (17) have established that the strongest zone of exposure lies within $500 \mathrm{~m}$ of major roads. ArcGIS software was used to assign each patient to a buffer zone.

\section{Statistical analysis}

Multinomial logistic and multivariate linear regression analyses were performed with SPSS version 16 (IBM Corporation, USA). Analyses were performed as follows: multinomial logistic regression with outcome of bronchitis subtypes, with reference category of patients classified as normal using the data from the stable and exacerbated databases; binomial logistic regression for diagnosis of asthma in both databases; and multivariate linear regression for lung function in the stable and exacerbated groups. All analyses were adjusted for patient age, smoking status - identified by macrophages with smokers' inclusions - and corticosteroid medications. In addition, the study controlled for temperature and humidity on the day of the patients' visits. Meteorological data were obtained from the Environment Canada meteorology station at the Hamilton International Airport. Spatial autocorrelation in the residuals of the models were found to be negligible, indicating no underlying, unaccounted spatial dependence in the models. It was not possible to determine possible associations between the subtypes of bronchitis within the asthma or COPD groups because of the small number of patients within each buffer zone.

\section{RESULTS}

The clinical characteristics of patients in stable and exacerbated phases are summarized in Table 1 . In the stable group, $34 \%$ of patients had asthma and $22 \%$ had COPD. In the exacerbated group, $41 \%$ and $37 \%$ of patients were diagnosed with asthma and COPD, respectively. All other diagnoses were grouped as 'all others', which included bronchiectasis and nonobstructive diseases such as sarcoidosis and pulmonary fibrosis.

\section{Exploratory analysis}

Table 2 summarizes the mean \pm SD of TCC and differential cell counts, as well as the number of patients with EB and NB within each buffer zone for both stable and exacerbated data sets. Overall, higher cell counts were observed in the exacerbated group. In the stable group, neutrophil percentages tended to be highest in the zones closest to roads and highways. In the exacerbated cases, TCC and eosinophil percentage were highest within $1 \mathrm{~km}$ of the industrial zone but neutrophil values did not vary greatly. 


\begin{tabular}{|c|c|c|c|c|c|c|}
\hline \multirow[b]{2}{*}{ Physician diagnosis (\%) } & \multicolumn{3}{|c|}{ Stable } & \multicolumn{3}{|c|}{ Exacerbated } \\
\hline & Asthma (34.4) & COPD (21.9) & All others (43.7) & Asthma (40.7) & COPD (37.0) & All others (22.2) \\
\hline Age, years & $47.5 \pm 17.9$ & $64.3 \pm 11$ & $56.7 \pm 15.3$ & $46.2 \pm 19.4$ & $66.3 \pm 12.9$ & $62.6 \pm 15.6$ \\
\hline Current or former smoker, $\%$ & 21 & 50 & 20.7 & 20.8 & 31.4 & 7.1 \\
\hline $\mathrm{FEV}_{1}, \%$ predicted & $87.9 \pm 23.5$ & $51.5 \pm 25.4$ & $91.0 \pm 27.6$ & $73.1 \pm 38.0$ & $44.6 \pm 30.2$ & $79.9 \pm 33.4$ \\
\hline $\mathrm{FEV}_{1} / \mathrm{NC}, \%$ & $73.1 \pm 16.9$ & $50.8 \pm 21.9$ & $75.7 \pm 18.2$ & $61.4 \pm 32.1$ & $43.2 \pm 26.9$ & $70.0 \pm 25.1$ \\
\hline Patients receiving ICS, \% & 63.5 & 64.1 & 25 & 27 & 23.8 & 6.9 \\
\hline Patients receiving prednisone, $\%$ & 2.2 & 3.5 & 1.9 & 4.8 & 7.9 & 2.1 \\
\hline
\end{tabular}

Data presented as mean \pm SD unless otherwise indicated; *Inhaled corticosteroid (ICS) dose calculated as beclomethasone dipropionate equivalents, in which $1 \mu \mathrm{g}$ beclomethasone $=1 \mu \mathrm{g}$ budesonide $=0.5 \mu \mathrm{g}$ fluticasone. COPD Chronic obstructive pulmonary disease; FEV ${ }_{1}$ Forced expiratory volume in $1 \mathrm{~s}$; VC Vital capacity

\section{TABLE 2}

Total cell counts (TCC) and differential sputum cell counts for patients with eosinophilic bronchitis (EB) and neutrophilic bronchitis (NB) living within each buffer zone for major roads, highways and industry

\begin{tabular}{|c|c|c|c|c|c|c|c|c|c|c|}
\hline \multirow[b]{3}{*}{ Buffer zone } & \multicolumn{5}{|c|}{ Stable } & \multicolumn{5}{|c|}{ Exacerbated } \\
\hline & \multirow[b]{2}{*}{ Eosinophils, \% } & \multirow[b]{2}{*}{ Neutrophils, \% } & \multirow[b]{2}{*}{ TCC, $\times 10^{6} / \mathrm{g}$} & \multicolumn{2}{|c|}{ Bronchitis, $n$} & \multirow[b]{2}{*}{ Eosinophils, \% } & \multirow[b]{2}{*}{ Neutrophils, \% } & \multirow[b]{2}{*}{$\mathrm{TCC}, \times 10^{6} / \mathrm{g}$} & \multicolumn{2}{|c|}{ Bronchitis, $n$} \\
\hline & & & & EB & NB & & & & EB & NB \\
\hline Total & $2.5 \pm 8.1$ & $61.2 \pm 27.1$ & $9.4 \pm 12.1$ & 121 & 124 & $4.1 \pm 11.3$ & $66.6 \pm 27.9$ & $19.3 \pm 26.4$ & 64 & 75 \\
\hline \multicolumn{11}{|l|}{ Major road, m } \\
\hline $0-100$ & $2.7 \pm 4.8$ & $74.4 \pm 24.7$ & $13.7 \pm 10.9$ & 24 & 18 & $1.4 \pm 2.3$ & $74.1 \pm 25.0$ & $23.4 \pm 21.8$ & 5 & 12 \\
\hline$>100-200$ & $5.6 \pm 13.5$ & $63.8 \pm 28.0$ & $12.5 \pm 12.0$ & 18 & 18 & $8.7 \pm 15.9$ & $70.2 \pm 27.5$ & $30.3 \pm 46.8$ & 13 & 10 \\
\hline$>200-300$ & $7.0 \pm 13.6$ & $63.6 \pm 24.8$ & $14.3 \pm 15.4$ & 28 & 17 & $8.8 \pm 15.4$ & $63.2 \pm 26.6$ & $9.1 \pm 8.5$ & 15 & 6 \\
\hline$>300-400$ & $6.9 \pm 15.9$ & $70.4 \pm 28.0$ & $11.4 \pm 9.5$ & 15 & 18 & $7.3 \pm 19.6$ & $74.5 \pm 24.7$ & $30.0 \pm 29.5$ & 8 & 12 \\
\hline Other & $4.0 \pm 8.4$ & $66.4 \pm 24.8$ & $19.4 \pm 17.7$ & 36 & 53 & $4.4 \pm 10.0$ & $71.9 \pm 27.3$ & $28.2 \pm 26.6$ & 23 & 35 \\
\hline \multicolumn{11}{|l|}{ Highway, m } \\
\hline $0-500$ & $5.7 \pm 15.1$ & $71.1 \pm 24.7$ & $18.5 \pm 20.4$ & 16 & 17 & $6.6 \pm 12.2$ & $71.6 \pm 25.3$ & $26.1 \pm 25.8$ & 6 & 8 \\
\hline$>$ >500-1000 & $6.2 \pm 11.9$ & $62.4 \pm 28.3$ & $10.4 \pm 9.3$ & 19 & 14 & $8.7 \pm 16.7$ & $72.5 \pm 25.7$ & $24.8 \pm 29.5$ & 4 & 10 \\
\hline$>1000-1500$ & $1.6 \pm 3.1$ & $73.4 \pm 18.5$ & $14.0 \pm 6.8$ & 15 & 18 & $5.4 \pm 11.7$ & $70.0 \pm 28.3$ & $33.4 \pm 51.8$ & 10 & 9 \\
\hline Other & $4.5 \pm 9.7$ & $68.1 \pm 27.2$ & $15.2 \pm 13.9$ & 71 & 75 & $4.9 \pm 13.5$ & $71.2 \pm 26.5$ & $22.3 \pm 21.6$ & 44 & 48 \\
\hline \multicolumn{11}{|l|}{ Industry, km } \\
\hline $0-1$ & $6.3 \pm 10.2$ & $66.1 \pm 23.3$ & $13.2 \pm 9.2$ & 13 & 15 & $9.0 \pm 18.4$ & $68.4 \pm 27.8$ & $30.1 \pm 52.0$ & 11 & 10 \\
\hline$>1-2$ & $4.1 \pm 10.3$ & $69.9 \pm 29.2$ & $16.0 \pm 13.8$ & 18 & 21 & $6.5 \pm 17.7$ & $67.1 \pm 29.2$ & $17.1 \pm 16.6$ & 8 & 11 \\
\hline$>2-3$ & $3.2 \pm 6.7$ & $67.3 \pm 25.5$ & $11.6 \pm 9.5$ & 16 & 14 & $5.5 \pm 12.8$ & $61.4 \pm 28.9$ & $18.2 \pm 17.3$ & 11 & 8 \\
\hline$>3-4$ & $7.3 \pm 12.8$ & $67.4 \pm 28.1$ & $10.6 \pm 7.4$ & 17 & 8 & $1.8 \pm 2.6$ & $84.1 \pm 14.2$ & $35.5 \pm 32.6$ & 5 & 10 \\
\hline Other & $4.6 \pm 11.9$ & $68.5 \pm 25.6$ & $17.2 \pm 17.8$ & 57 & 66 & $4.9 \pm 10.5$ & $72.7 \pm 26.1$ & $24.8 \pm 22.1$ & 29 & 36 \\
\hline
\end{tabular}

Data presented as mean \pm SD unless otherwise indicated

Table 3 shows similar statistics for patients with asthma and COPD. Stable asthma eosinophil percentages peaked at $200 \mathrm{~m}$ to $300 \mathrm{~m}$ from major roads, while percentages in the exacerbated group were highest at $100 \mathrm{~m}$ to $200 \mathrm{~m}$ from major roads, within $1 \mathrm{~km}$ of major highways and within $1 \mathrm{~km}$ of industry. Neutrophil percentages did not vary greatly except for a spike $3 \mathrm{~km}$ to $4 \mathrm{~km}$ from the industrial zone. This peak was also observed in the exacerbated COPD group and was accompanied by high TCCs.

Regression analysis - bronchitis subtypes, asthma and COPD

Logistic regression analysis for bronchitis subtypes in the stable group revealed that patients who lived $3 \mathrm{~km}$ to $4 \mathrm{~km}$ from the industrial zone showed increased risk of EB (OR 4.77 [95\% CI 1.62 to 14.05]; $\mathrm{P}=0.05$ ) (Table 4). This suggests that proximity to industry is not directly associated with these diagnoses. The $3 \mathrm{~km}$ to $4 \mathrm{~km}$ buffer around the industrial zone is located at the base of the Niagara escarpment (Figure 2), which is known to restrict air flow in this lower part of the city. Hence, the observed effect may have resulted from a combination of industry emissions and the accumulation of pollution at the base of the escarpment. There was an increased odds of NB within $1 \mathrm{~km}$ of major highways (OR 4.69 [95\% CI 1.18 to 18.67]; $\mathrm{P}=0.028$ ). Living within $1 \mathrm{~km}$ of a highway was associated with asthma in the stable group (OR 1.78 [95\%
CI 1.12 to 2.83]; $\mathrm{P}=0.016)$. Living within $1 \mathrm{~km}$ of industry was marginally significant $(\mathrm{P}=0.06)$ for increased odds of asthma in the stable group, and is consistent with the relatively high eosinophil percentage observed in this zone. The odds of COPD also increased within $2 \mathrm{~km}$ to $3 \mathrm{~km}$ of industry (OR 2.68 [95\% CI 1.28 to 5.68]; $\mathrm{P}=0.009$ ).

Within the exacerbated group, there was a decreased risk of EB for patients residing within $1 \mathrm{~km}$ to $1.5 \mathrm{~km}$ of highways (OR 0.35 [95\% CI 0.12 to 0.98 ]; $\mathrm{P}=0.045$ ). There were no statistically significant positive relationships between subtypes of exacerbated bronchitis and major roads, highways or industry. However, the significance of EB at $200 \mathrm{~m}$ to $300 \mathrm{~m}$ from major roads was noteworthy $(\mathrm{P}=0.065)$.

Proximity to roads, lung function and bronchitis

Multivariate linear regression analysis identified no significant association between lung function and proximity to highways or major roads in either the stable or exacerbated groups. However, when the stable data set was divided into sex subgroups, the effect of proximity to major roads on lung function was more pronounced in women than in men (Table 5). Women living within $200 \mathrm{~m}$ of a major road had significantly lower $\mathrm{FEV}_{1}(\mathrm{~B}=-0.17 ; \mathrm{P}=0.029)$, VC $(\mathrm{B}=-0.27$; $\mathrm{P}=0.002)$ and $\mathrm{VC} \%(\mathrm{~B}=-4.95 ; \mathrm{P}=0.037)$ compared with women living further away. This effect was not observed in the analysis of the 
TABLE 3

Total cell counts (TCC) and differential sputum cell counts for patients living within each buffer zone for major roads, highways and industry

\begin{tabular}{|c|c|c|c|c|c|c|c|c|}
\hline \multirow[b]{2}{*}{ Buffer zone } & \multicolumn{4}{|c|}{ Stable asthma } & \multicolumn{4}{|c|}{ Stable chronic obstructive pulmonary disease } \\
\hline & Patients, $\mathbf{n}$ & Eosinophils, \% & Neutrophils, \% & TCC, $\times 10^{6} / \mathrm{g}$ & Patients, $\mathbf{n}$ & Eosinophils, \% & Neutrophils, $\%$ & TCC $\times 10^{6} / \mathrm{g}$ \\
\hline \multicolumn{9}{|l|}{ Major roads, $\mathrm{m}$} \\
\hline $0-100$ & 24 & $2.3 \pm 5.5$ & $55.5 \pm 30.3$ & $8.9 \pm 9.5$ & 29 & $0.6 \pm 0.8$ & $78.2 \pm 15.0$ & $8.4 \pm 10.0$ \\
\hline$>200-300$ & 28 & $6.2 \pm 14.9$ & $59.9 \pm 26.9$ & $10.1 \pm 11.8$ & 15 & $1.7 \pm 3.9$ & $74.0 \pm 24.2$ & $13.7 \pm 21.4$ \\
\hline$>300-400$ & 26 & $4.3 \pm 14.0$ & $55.1 \pm 32.5$ & $6.2 \pm 6.7$ & 16 & $1.1 \pm 1.7$ & $69.7 \pm 18.6$ & $8.8 \pm 9.2$ \\
\hline 0-1000 & 57 & $3.9 \pm 11.8$ & $51.8 \pm 31.6$ & $7.0 \pm 8.3$ & 19 & $4.9 \pm 13.2$ & $67.3 \pm 29.7$ & $26.7 \pm 26.9$ \\
\hline$>1000-1500$ & 22 & $1.7 \pm 3.8$ & $62.4 \pm 26.4$ & $8.9 \pm 7.4$ & 12 & $0.7 \pm 1.1$ & $74.4 \pm 24.2$ & $7.9 \pm 4.9$ \\
\hline Other & 88 & $4.9 \pm 11.5$ & $52.6 \pm 28.8$ & $8.0 \pm 9.8$ & 66 & $0.8 \pm 2.5$ & $75.2 \pm 19.3$ & $11.7 \pm 15.1$ \\
\hline \multicolumn{9}{|l|}{ Industry, km } \\
\hline $0-1$ & 24 & $5.4 \pm 9.5$ & $52.9 \pm 22.1$ & $7.9 \pm 6.5$ & 15 & $0.6 \pm 1.0$ & $69.9 \pm 27.9$ & $9.3 \pm 8.2$ \\
\hline Other & & \multicolumn{3}{|c|}{ Exacerbated asthma } & \multicolumn{4}{|c|}{ Exacerbated chronic obstructive pulmonary disease } \\
\hline \multicolumn{9}{|l|}{ Major roads, m } \\
\hline 0-100 & 7 & $1.0 \pm 1.7$ & $61 . \pm 31.7$ & $12.4 \pm 14.3$ & 8 & $1.0 \pm 2.2$ & $78.4 \pm 26.4$ & $26.4 \pm 29.9$ \\
\hline$>100-200$ & 11 & $13.4 \pm 21.8$ & $53.1 \pm 27.7$ & $10.2 \pm 10.8$ & 12 & $2.3 \pm 3.7$ & $68.1 \pm 30.0$ & $17.7 \pm 24.2$ \\
\hline$>200-300$ & 18 & $8.5 \pm 16.1$ & $62.8 \pm 27.0$ & $6.4 \pm 5.8$ & 8 & $1.0 \pm 1.1$ & $67.6 \pm 25.3$ & $9.1 \pm 10.1$ \\
\hline$>300-400$ & 12 & $11.1 \pm 25.0$ & $56.8 \pm 36.9$ & $26.3 \pm 32.6$ & 13 & $1.1 \pm 2.0$ & $72.9 \pm 20.8$ & $22.5 \pm 25.6$ \\
\hline Other & 29 & $6.5 \pm 13.4$ & $60.5 \pm 31.0$ & $18.0 \pm 22.2$ & 21 & $2.5 \pm 6.6$ & $75.5 \pm 23.3$ & $26.9 \pm 29.4$ \\
\hline \multicolumn{9}{|l|}{ Highways, m } \\
\hline $0-1000$ & 15 & $10.2 \pm 18.0$ & $65.7 \pm 29.8$ & $12.7 \pm 10.2$ & 18 & $3.4 \pm 7.5$ & $68.5 \pm 25.0$ & $23.3 \pm 31.5$ \\
\hline$>1000-1500$ & 14 & $4.8 \pm 12.6$ & $62.3 \pm 32.4$ & $22.0 \pm 26.7$ & 6 & $1.6 \pm 2.0$ & $52.3 \pm 26.2$ & $5.4 \pm 6.7$ \\
\hline
\end{tabular}

Data presented as mean \pm SD unless otherwise indicated

TABLE 4

Results of logistic regression analyses for bronchitis subtype, asthma and chronic obstructive pulmonary disease (COPD) according to proximity to major roads, highways and industry

\begin{tabular}{|c|c|c|c|c|c|c|}
\hline \multicolumn{7}{|l|}{ Stable group } \\
\hline Outcome & Independent variable & B & SE & $\mathbf{P}$ & $\operatorname{Exp}(B)$ & $95 \% \mathrm{Cl}$ \\
\hline Eosinophilic bronchitis & $3 \mathrm{~km}$ to $4 \mathrm{~km}$ from industry & 1.56 & 0.55 & 0.005 & 4.77 & $1.62-14.05$ \\
\hline Neutrophilic bronchitis & $1 \mathrm{~km}$ from highway & 1.55 & 0.71 & 0.028 & 4.69 & $1.18-18.67$ \\
\hline Neutrophilic bronchitis & $3 \mathrm{~km}$ to $4 \mathrm{~km}$ from industry & 0.71 & 0.61 & 0.245 & 2.04 & $0.61-6.80$ \\
\hline \multirow[t]{2}{*}{ Asthma } & $0 \mathrm{~km}$ to $1 \mathrm{~km}$ from highway & 0.57 & 0.24 & 0.016 & 1.78 & $1.12-2.83$ \\
\hline & $0 \mathrm{~km}$ to $1 \mathrm{~km}$ from industry & 0.59 & 0.32 & 0.061 & 1.81 & $0.97-3.36$ \\
\hline COPD & $2 \mathrm{~km}$ to $3 \mathrm{~km}$ from industry & 0.99 & 0.38 & 0.009 & 2.68 & $1.28-5.64$ \\
\hline \multicolumn{7}{|l|}{ Exacerbated group } \\
\hline Asthma & $200 \mathrm{~m}$ to $300 \mathrm{~m}$ from major road & 1.58 & 0.59 & 0.008 & 4.85 & $1.52-15.53$ \\
\hline COPD & $3 \mathrm{~km}$ to $4 \mathrm{~km}$ from industry & 1.80 & 0.67 & 0.007 & 6.04 & $1.625-22.47$ \\
\hline
\end{tabular}

subgroup of men. Similar results were observed for $\mathrm{FEV}_{1}(\mathrm{~B}=-0.16$; $\mathrm{P}=0.036)$ and $\mathrm{VC}(\mathrm{B}=-0.23 ; \mathrm{P}=0.008)$ in women living within $300 \mathrm{~m}$ of a major road. However within this $300 \mathrm{~m}$ buffer zone, men also exhibited decreased VC $(B=-0.34 ; P=0.037)$ and $\mathrm{VC} \%(B=-5.4$; $\mathrm{P}=0.037)$. The mean $( \pm \mathrm{SD})$ for these lung function parameters in women were as follows: $\mathrm{FEV}_{1} 2.1 \pm 1.1 \mathrm{~L} / \mathrm{min}, \mathrm{VC} 2.8 \pm 1.2 \mathrm{~L} / \mathrm{min}$ and VC\% 91.4 $\pm 28.7 \%$; in men: $\mathrm{FEV}_{1} 2.7 \pm 1.3 \mathrm{~L} / \mathrm{min}, \mathrm{VC} 3.9 \pm 1.5 \mathrm{~L} / \mathrm{min}$ and $\mathrm{VC} \% 86.8 \pm 25.1 \%$. Analysis of the exacerbated group according to sex was not possible because of the small number of patients in this group. 
TABLE 5

Results of multivariate linear regression analysis for outcomes of lung function in men and women of the stable subgroup living in buffer zones $200 \mathrm{~m}$ and $300 \mathrm{~m}$ from major roads

\begin{tabular}{|c|c|c|c|c|c|c|c|c|}
\hline \multirow{2}{*}{$\begin{array}{l}\text { Outcome } \\
\text { measure }\end{array}$} & \multirow{2}{*}{$\begin{array}{c}\text { Buffer } \\
\text { zone, } \mathrm{m}\end{array}$} & \multirow[b]{2}{*}{ Sex } & \multirow{2}{*}{$\begin{array}{c}\text { Patients in } \\
\text { buffer zone, } \mathbf{n}\end{array}$} & \multicolumn{2}{|c|}{ Unstandardized coefficients } & \multirow[b]{2}{*}{$\mathbf{P}$} & \multirow[b]{2}{*}{$95 \% \mathrm{Cl}$ for $\mathrm{B}$} & \multirow[b]{2}{*}{$\mathbf{R}^{2}$} \\
\hline & & & & B & SE & & & \\
\hline \multirow[t]{2}{*}{$\mathrm{FEV}_{1}$} & 200 & Female & 59 & -0.17 & 0.08 & 0.029 & -0.32 to -0.02 & 0.48 \\
\hline & & Male & 94 & -0.02 & 0.15 & 0.911 & -0.32 to 0.28 & 0.29 \\
\hline \multirow[t]{2}{*}{$\mathrm{FEV}_{1}$} & 300 & Female & 96 & -0.16 & 0.07 & 0.036 & -0.30 to -0.01 & 0.49 \\
\hline & & Male & 131 & -0.18 & 0.14 & 0.203 & -0.46 to 0.10 & 0.30 \\
\hline \multirow[t]{2}{*}{ VC } & 200 & Female & 59 & -0.27 & 0.09 & 0.002 & -0.44 to -0.10 & 0.40 \\
\hline & & Male & 94 & -0.02 & 0.18 & 0.918 & -0.37 to 0.33 & 0.13 \\
\hline \multirow[t]{2}{*}{ VC } & 300 & Female & 96 & -0.23 & 0.08 & 0.008 & -0.39 to -0.06 & 0.39 \\
\hline & & Male & 131 & -0.34 & 0.16 & 0.037 & -0.66 to -0.02 & 0.15 \\
\hline \multirow[t]{2}{*}{ VC, $\%$} & 200 & Female & 59 & -4.95 & 2.36 & 0.037 & -9.6 to -0.31 & 0.12 \\
\hline & & Male & 94 & -0.05 & 2.83 & 0.985 & -5.63 to 5.52 & 0.13 \\
\hline \multirow[t]{3}{*}{ VC, $\%$} & 300 & Female & 96 & -3.52 & 2.29 & 0.125 & -8.02 to 0.99 & 0.11 \\
\hline & & Male & 131 & -5.4 & 2.59 & 0.037 & -10.53 to -0.33 & 0.15 \\
\hline & & $\begin{array}{l}\mathrm{FEV}_{1}, \mathrm{~L} / \mathrm{min} \\
(\mathrm{mean} \pm \mathrm{SD})\end{array}$ & & \multicolumn{2}{|c|}{$\begin{array}{l}\text { Vital capacity, L/min } \\
\quad(\text { mean } \pm S D)\end{array}$} & & \multicolumn{2}{|l|}{$\begin{array}{l}\text { Vital capacity, \% } \\
\quad(\text { mean } \pm \text { SD) }\end{array}$} \\
\hline \multicolumn{2}{|l|}{ Women } & \multicolumn{2}{|l|}{$2.1 \pm 1.1$} & \multicolumn{2}{|c|}{$2.8 \pm 1.2$} & & \multicolumn{2}{|l|}{$91.4 \pm 28.7$} \\
\hline Men & & \multicolumn{2}{|l|}{$2.7 \pm 1.3$} & \multicolumn{2}{|c|}{$3.9 \pm 1.5$} & & \multicolumn{2}{|l|}{$86.8 \pm 25.1$} \\
\hline
\end{tabular}

FEV 1 Forced expiratory volume in $1 \mathrm{~s}$

\section{DISCUSSION}

The present retrospective study demonstrated associations between residential proximity to air pollution from motor vehicle traffic, and inflammatory subtypes of bronchitis and exacerbations in patients with obstructive lung disease. Proximity to major highways increased the risk of bronchitis, especially NB, and proximity to major roads was associated with lower lung function.

The current study was the first to examine the association between valid and reliable quantitative cell counts in sputum and residential proximity to traffic pollution. Our findings were consistent with those of a study conducted 30 years previously (18) that identified an association between NB and air pollution exposure, with no similar association with EB. This is of interest given that sputum cell counts were not standardized, and GIS methods were less advanced at that time. Furthermore, asthmatic patients who spent $2 \mathrm{~h}$ walking on streets exposed to diesel pollution demonstrated an acute (but nonsignificant) increase in neutrophils with no increase in eosinophils (9), and traffic police officers exhibited increased airway neutrophil inflammation (10). Our work using objective measures is also supported by studies of random populations of both adults and children using questionnaire-based surveys $(4-8,19,20)$, which identified associations between patients with reported symptoms of chronic cough or phlegm and increased traffic density.

There is a significant amount of in vivo evidence supporting that neutrophils are unregulated in the presence of a variety of air pollutants (eg, nitrogen dioxide and ozone) in both healthy (21) and asthmatic subjects (22), which suggests that the production of neutrophils is upregulated via interleukin 8 (23). We do not know whether NB in some subjects was associated with bacterial or viral infections because culture data were not available. It is difficult to determine the reason for the lower risk for EB, which could be explained by an inadequate concentration of air pollutants that may not be powerful enough to promote airway eosinophilia. Because we did not have information on sputum cells after treatment of $\mathrm{NB}$ with an antibiotic, we cannot exclude the possibility of NB masking sputum eosinophils (24). Perhaps air pollution elicits a $\mathrm{T}$ helper cell-1-like immune modulation effect similar to cigarette smoke, which has been shown to lower the risk of allergic sensitization and this may be another reason that we did not detect eosinophils (25). This, however, needs further prospective evaluation.
Similar to a large cohort study from the United States (26), we found that the effect of traffic pollution on lung function was more pronounced in women than in men; however, the mechanisms need further investigation. Our data in adults with lung disease may be significant because similar associations between lung function decline and traffic pollution were observed in a significantly smaller number of individuals. Exposure to air pollution from traffic sources has demonstrated long-term declines in lung function during an important period of growth in large numbers of children (7). Furthermore, in children with persistent asthma, a short-term effect (five days) has been associated with acute decreases in lung function concomitant with increases in respiratory symptoms (27), as well as in asthmatic adults with even shorter exposure $(2 \mathrm{~h})$ to diesel particulates (9).

In contrast to other published studies, we did not find an association between residential proximity to a highway and stable or exacerbated COPD (28). This is interesting considering that the neutrophilia observed in our COPD patients was generally more severe; however, the inadequate number of patients in this group precluded us from dividing the group into subgroups for reliable multinomial analyses. However, considering our findings of increased neutrophil percentage in patients with COPD, it may suggest that the neutrophilia present in COPD is a feature of the disease rather than being modified by air pollutants.

The strengths of the present study were the reliable and valid measurements of airway inflammation that were made blinded to the patients' clinical details, and the geospatial analyses that enabled us to relate measurement of bronchitis to exposure to pollution from vehicular traffic in an urban population. The spatial extent of impact for mobile pollution sources reviewed in the present study was on the order of $100 \mathrm{~m}$ to $400 \mathrm{~m}$ for elemental carbon or particulate matter mass concentration (excluding background concentration), $200 \mathrm{~m}$ to $500 \mathrm{~m}$ for nitrogen dioxide and $100 \mathrm{~m}$ to $300 \mathrm{~m}$ for ultrafine particle counts (17). For Hamilton, we have similarly demonstrated that pollutants such as NOx are highest close to major highways. Hence, despite the complexity of the Hamilton pollution landscape, we believe that information can be gleaned from highway proximity analyses. The current study was limited by its retrospective design and, therefore, did not allow us to account for other factors such as the patient's length of occupancy at their address, indoor pollution, secondhand smoke exposure, socioeconomic status, occupation, atopy, 
early childhood exposure to pollutants, treatment effect with antibiotic, and deficits of dietary factors or genetic antioxidant defenses that can increase susceptibility to air pollution - all of which need prospective evaluation.

\section{CONCLUSION}

Results of the present retrospective study indicate that the presence of bronchitis, an asthma diagnosis and exacerbations of the disease are, to some extent, predictive based on residential proximity to air pollutants from vehicular traffic emissions in patients with lung disease who live in an urban environment and attended a tertiary care centre. The current study also highlighted the importance of neutrophils as cells involved in airway disease, and that neutrophils play a role that may be amplified by nonallergic environmental stimuli such as air pollutants. The study also demonstrated that GIS and sputum cell counts can be used to study biological effects of air pollution in the community. Further prospective studies would assist in confirming these findings, and would also assess the role of other environmental stimuli (eg, allergens), current therapies and respiratory infections associated with exposure to vehicular traffic pollutants.

FUNDING: This study was supported by the McMaster University (Hamilton, Ontario) Collaboration for Health Seed Grant, Hamilton Community Foundation Education Grant, and a GlaxoSmithKlineFirestone Institute Collaboration Grant. Dr Kanaroglou holds a Canada Research Chair in Spatial Analysis, and Dr Nair holds a Canada Research Chair in Airway Inflammometry. Dr Brannan is supported by an Asthma Foundation of New South Wales (Australia) Fellowship.

ACKNOWLEDGEMENTS: The authors thank Ann Efthimiadis (McMaster University) for performing the sputum cell counts, Dr Chris Allen (McMaster University) for setting up the sputum database and Dr Piush Mandhane (University of Alberta, Edmonton, Alberta) for developing the concept of this study.

\section{REFERENCES}

1. Künzli N, Kaiser R, Medina S, et al. Public-health impact of outdoor and traffic-related air pollution: A European assessment. Lancet 2000;356:795-801.

2. Kim JJ, Smorodinsky S, Lipsett M, Singer BC, Hodgson AT, Ostro B. Traffic-related air pollution near busy roads: The East Bay Children's Respiratory Health Study. Am J Respir Crit Care Med 2004;170:520-6.

3. Hwang BF, Lee YL, Lin YC, Jaakkola JJ, Guo YL. Traffic related air pollution as a determinant of asthma among Taiwanese school children. Thorax 2005;60:467-73.

4. Venn AJ, Lewis SA, Cooper M, Hubbard R, Britton J. Living near a main road and the risk of wheezing illness in children.

Am J Respir Crit Care Med 2001;164:2177-80.

5. Morgenstern V, Zutavern A, Cyrys J, et al; GINI Study Group; LISA Study Group. Atopic diseases, allergic sensitization, and exposure to traffic-related air pollution in children. Am J Respir Crit Care Med 2008;177:1331-7.

6. Holguin F, Flores S, Ross Z, et al. Traffic-related exposures, airway function, inflammation, and respiratory symptoms in children. Am J Respir Crit Care Med 2007;176:1236-42.
7. Gauderman WJ, Vora H, McConnell R, et al. Effect of exposure to traffic on lung development from 10 to 18 years of age: A cohort study. Lancet 2007;369:571-7.

8. Halonen JI, Lanki T, Yli-Tuomi T, Kulmala M, Tiittanen P, Pekkanen J. Urban air pollution, and asthma and COPD hospital emergency room visits. Thorax 2008;63:635-41.

9. McCreanor J, Cullinan P, Nieuwenhuijsen MJ, et al. Respiratory effects of exposure to diesel traffic in persons with asthma. N Engl J Med 2007;357:2348-58.

10. Dragonieri S, Musti M, Izzo C, et al. Sputum induced cellularity in a group of traffic policemen. Sci Total Environ 2006;367:433-6.

11. Larsson BM, Sehlstedt M, Grunewald J, et al. Road tunnel air pollution induces bronchoalveolar inflammation in healthy subjects. Eur Respir J 2007;29:699-705.

12. Romieu I, Barraza-Villarreal A, Escamilla-Nuñez C, et al. Exhaled breath malondialdehyde as a marker of effect of exposure to air pollution in children with asthma. J Allergy Clin Immunol 2008;121:903-9.

13. Hargreave FE. Quantitative sputum cell counts as a marker of airway inflammation in clinical practice. Curr Opin Allergy Clin Immunol 2007;7:102-6.

14. Finkelstein MM, Jerrett M, Sears MR. Traffic air pollution and mortality rate advancement periods. Am J Epidemiol 2004;160:173-7.

15. Belda J, Leigh R, Parameswaran K, O'Byrne PM, Sears MR, Hargreave FE. Induced sputum cell counts in healthy adults. Am J Respir Crit Care Med 2000;161:475-8.

16. Pizzichini E, Pizzichini MM, Efthimiadis A, Hargreave FE, Dolovich J. Measurement of inflammatory indices in induced sputum: Effects of selection of sputum to minimize salivary contamination. Eur Respir J 1996;9:1174-80.

17. Zhou Y, Levy JI. Factors influencing the spatial extent of mobile source air pollution impacts: A meta-analysis. BMC Public Health 2007;7:89.

18. Nobutomo K. Air pollution and cytological changes in sputum. Lancet 1978;1:523-6.

19. Sunyer J, Jarvis D, Gotschi T, et al. Chronic bronchitis and urban air pollution in an international study. Occup Environ Med 2006;63:836-43.

20. Levy D, Gent M, Newhouse MT. Relationship between acute respiratory illness and air pollution levels in an industrial city. Am Rev Respir Dis 1977;116:167-73.

21. Bosson J, Barath S, Pourazar J, et al. Diesel exhaust exposure enhances the ozone-induced airway inflammation in healthy humans. Eur Respir J 2008;31:1234-40.

22. Nightingale JA, Rogers DF, Barnes PJ. Effect of inhaled ozone on exhaled nitric oxide, pulmonary function, and induced sputum in normal and asthmatic subjects. Thorax 1999;54:1061-9.

23. Barnes PJ. Air pollution and asthma: Molecular mechanisms. Mol Med Today 1995;1:149-55.

24. D'silva L, Allen CJ, Hargreave FE, Parameswaran K. Sputum neutrophilia can mask eosinophilic bronchitis during exacerbations. Can Respir J 2007;14:281-4.

25. Hancox RJ, Welch D, Poulton R, et al. Cigarette smoking and allergic sensitization: A 32-year population-based cohort study. J Allergy Clin Immunol 2008;121:8-42.

26. Kan H, Heiss G, Rose KM, Whitsel E, Lurmann F, London SJ. Traffic exposure and lung function in adults: The Atherosclerosis Risk in Communities study. Thorax 2007;62:873-9.

27. O'Connor GT, Neas L, Vaughn B, et al. Acute respiratory health effects of air pollution on children with asthma in US inner cities. J Allergy Clin Immunol 2008;121:1133-9.

28. Schikowski T, Sugiri D, Ranft U, et al. Long-term air pollution exposure and living close to busy roads are associated with COPD in women. Respir Res 2005;6:152-62. 


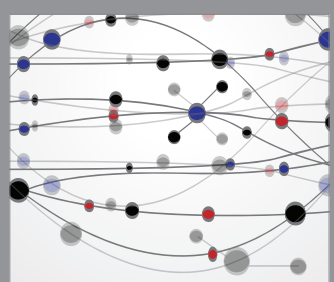

The Scientific World Journal
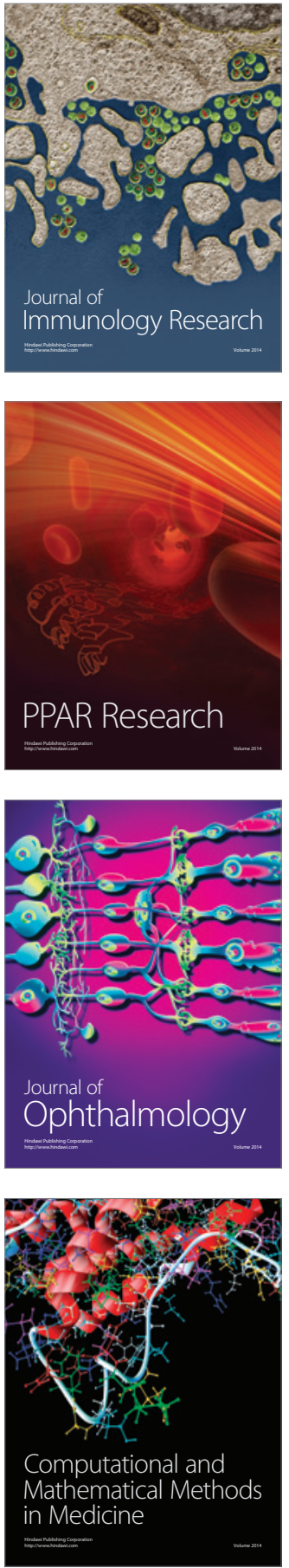

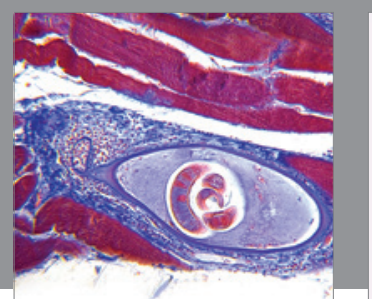

Gastroenterology Research and Practice

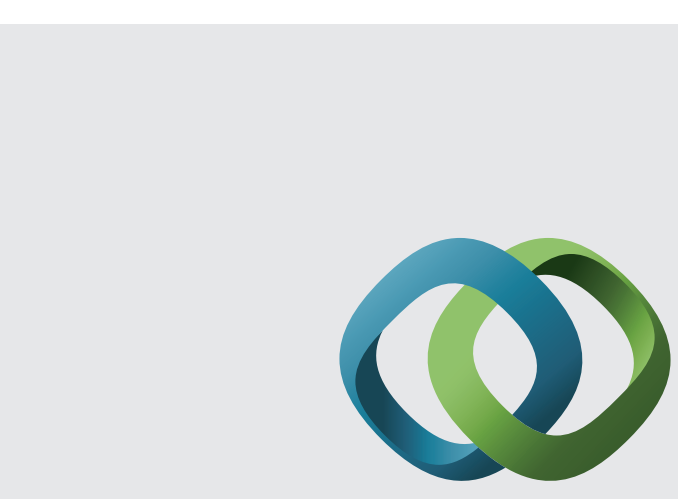

\section{Hindawi}

Submit your manuscripts at

http://www.hindawi.com
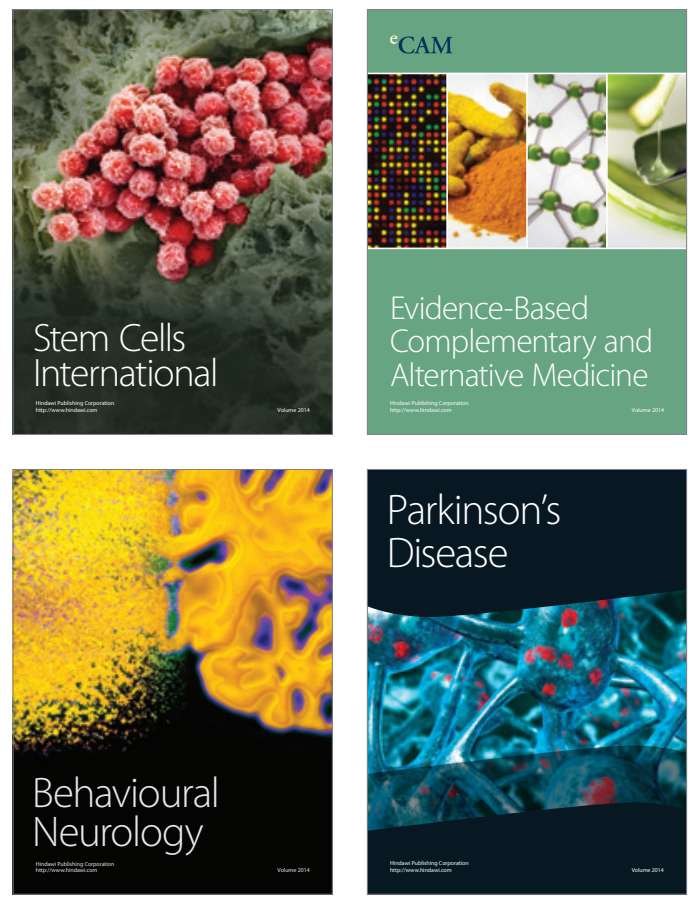
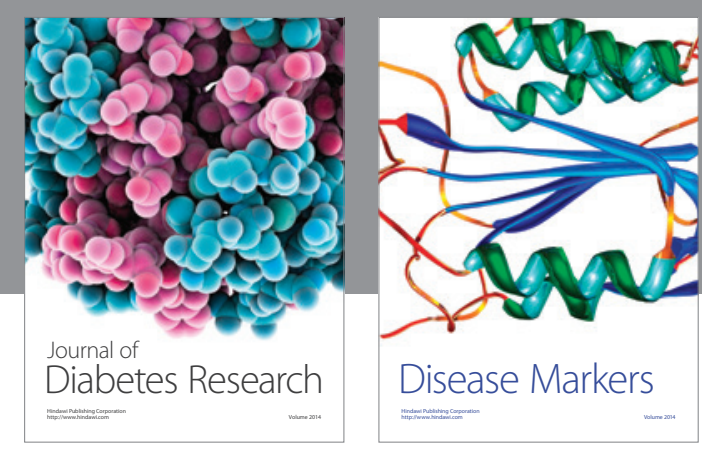

Disease Markers
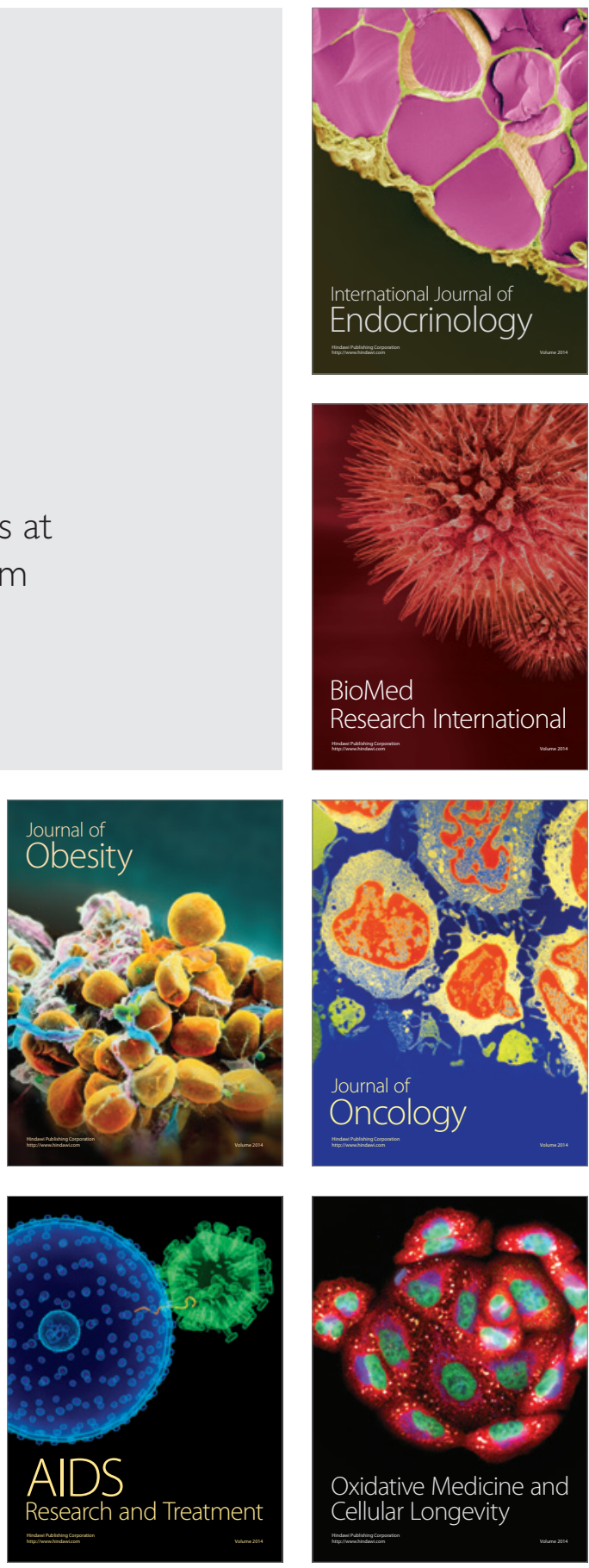